
The chilean parliamentary presidency under the political constitution of 1925: A regulatory and institutional study
Iván Obando Camino Pp. 209 a 227

\title{
THE CHILEAN PARLIAMENTARY PRESIDENCY UNDER THE POLITICAL CONSTITUTION OF 1925: A REGULATORY AND INSTITUTIONAL STUDY ${ }^{1}$
}

\author{
La presidencia parlamentaria chilena bajo la Constitución Politica de 1925: Estudio \\ normativo e institucional
}

Iván Obando Camino*

\begin{abstract}
${ }^{1}$ El autor agradece el apoyo de Conicyt para esta investigación, mediante el Proyecto de Investigación Conicyt/Fondecyt/Iniciación/No11130543, titulado "Desarrollo institucional del Congreso Nacional, 1834-2010: ¿ Institucionalización legislativa, des-institucionalización, o reinstitucionalización?" Este trabajo tiene como antecedente el artículo titulado "The apprenticeship of Chilean congressional leaders (1834-1924) from the perspective of the theory of legislative institutionalization", publicado en la Revista Chilena de Derecho y Ciencia Politica 2, No 2, 2011, pp. 107-132 y continúa esta línea de indagación refiriéndose al periodo siguiente de la historia constitucional chilena.
\end{abstract}

Este artículo fue enviado a revisión inicialmente en español y ha sido traducido al inglés gracias al Proyecto FP150008, "Aumento y mejora del índice de impacto y de la internacionalización de la revista Universum por medio de la publicación de un mayor número de artículos en inglés". Fondo de Publicación de Revistas Científicas 2015, Programa de Información Científica, Comisión Nacional de Investigación Científica y Tecnológica (Conicyt), Chile.

This article was initially submitted for review in Spanish, and it has been translated into English with the support of the Project FP150008, "Aumento y mejora del índice de impacto y de la internacionalización de la revista Universum por medio de la publicación de un mayor número de artículos en inglés." Fund for publication of Scientific Journals 2015, Scientific Information Program, Scientific and Technological Research National Commission (Conicyt), Chile.

* Profesor de la Universidad de Talca. Abogado y Doctor por SUNY-Albany. Facultad de Ciencias Jurídicas y Sociales. Talca, Chile. Correo electrónico: iobandoc@utalca.cl.

Article received March 24, 2015. Accepted July 24, 2015. 


\section{SUMMARY}

This article is a regulatory and institutional study about the Presidency of the Senate and the House of Deputies under the Constitution of 1925. This article maintains that both Presidencies constituted constitutional offices whose holders exercised political authority impartially, despite the partisan origin of these positions. These circumstances configured them as an intermediate model of parliamentary Presidency in comparative terms. These Presidencies interested parliamentary leaders for instrumental reasons that had to do with their political career, but within a power structure that relied on political parties with parliamentary majority, resulting in an increase in the average parliamentary experience of those elected to these positions.

Keywords: Parliamentary presidency, constitutional office, legislature.

\section{RESUMEN}

Este artículo consiste en un estudio normativo e institucional sobre la Presidencia del Senado y de la Cámara de Diputados bajo la Constitución Política de 1925. Este trabajo sostiene que ambas Presidencias constituyeron magistraturas constitucionales ejercidas por sus titulares imparcialmente, no obstante el origen partidista de quienes ocuparon este cargo. Estas circunstancias la configuraron como un modelo intermedio de presidencia parlamentaria en términos comparados. Ambas Presidencias interesaron a líderes parlamentarios por razones instrumentales, vinculadas a la proyección de su carrera política, pero dentro de una estructura de poder resguardada por los partidos políticos con mayoría parlamentaria, produciéndose un aumento del promedio de experiencia parlamentaria de los elegidos a dichos cargos.

Palabras clave: Presidencia parlamentaria, magistratura constitucional, asamblea legislativa.

\section{INTRODUCTION}

A legislature can aggregate interests, structure decisions and pass authoritative policies in a democracy. In order to do so, it should institutionalize itself over time and become a relevant actor in the political system.

The parliamentary presidencies of the houses of a legislature play a role in this process. They are part of the limited number of existing legislative offices in a political system, which are attractive for politicians because they have legal authority to carry out certain parliamentarian tasks and have institutional features that influence their perception by the political elite (Jenny and Müller, 1995). Not least important are those who hold these offices over time, as they contribute 
to provide permanence and continuity to the legislature through the competent performance of their duties, for which purpose converge peers expectations and the experience of the office holder.

The study of these offices and their holders contributes to an explanation of the historical development and roles of parliamentary institutions. Indeed, the study of the regulatory framework of the parliamentary presidency makes possible to determine its structure in accordance with the relevant provisions of the constitution and the standing orders. On the other hand, the study of its institutional aspects allows determining its institutional features and the type of parliamentary presidency developed in our country in a broad sense. Finally, the study of the dynamics generated around these institutions allows us to understand how the parliamentary elite appreciated the aforementioned offices.

Under the rule of the autocratic regime established by the Constitution of 1833, the Presidency of each house of the Chilean legislature constituted an internal administrative offices controlled by the parliamentary majority. Next to the President, there were one or two Vice Presidents in each house, whose only parliamentary duty consisted of subrogating the President in case of absence or illness. None of these offices had the authority to subrogate the President of the Republic, unlike the previous constitution, so their holders were mere legislative officials in charge of the administration and representation of the respective house. The parliamentary majority controlled these offices -and their holders, through the monthly duration of these positions until the early twentieth century, despite a general expectation of impartiality on the part of the office holders. In this period, it was not uncommon the election to these offices of newly elected Congress members, that a Congress member occupied any of these offices more than once in his or her parliamentary career, that some of them resigned these positions earlier, and that the election to these offices required a rather modest parliamentary experience.

The Constitution of 1925 changed the constitutional and political context of the Chilean legislature, better known as the National Congress. It introduced a presidential government consisting of a strengthened presidency and a streamlined legislature, operating under a newly minted multiparty system based on the capital-labor conflict, with disciplined and ideological parties that presided over the gradual democratization of the political system. One wonders, then, if the Presidency and Vice Presidency of each house of the Chilean legislature varied in its regulatory structure as well as in its institutional aspects and dynamics under the political regime that developed after the enactment of this constitution.

For this purpose, this article analyzes the regulatory framework of the aforementioned offices from a juridical-dogmatic perspective, as well as their institutional aspects and dynamics from a historical-institutional perspective. 
Research on the regulatory framework of these offices drew from Anales de la Repuiblica, successive editions of the Manual del Senado, and the standing orders of the House of Deputies. In turn, research on the institutional aspects and dynamics of the same offices drew from episodic records of the period, compilations of data on parliamentary activity, including Anales de la República, and interviews with former officials and Congress members.

In general terms, this article maintains that the aforementioned Presidencies -and the Vice Presidencies by extent, became constitutional offices after the passage of the Constitution of 1925, while keeping most of the powers and structural aspects of the previous period. Notwithstanding their holders came from political parties of the parliamentary majority, to the extent that they could vote and speak on the floor, there was a broad expectation for an impartial and non-partisan performance of the duties and authority vested in these offices, which swayed Congress to pass regulatory reforms to strengthen them. The latter placed these offices halfway between a partisan and a non-partisan model of parliamentary Presidency, identified with the American and the British Speakership, respectively. Unlike the previous period, these offices interested Congress members for reasons related to the projection of their political careers, but within a power structure that relied on the aforementioned political parties.

This article consists of five sections, including this Introduction and the Conclusion. The second section analyzes the regulatory framework of the Chilean parliamentary Presidency in the period investigated herein, including both the Presidency and the Vice Presidency of each house. The third section discusses the institutional aspects of these offices. Finally, the fourth section refers to the institutional dynamics generated in connection with these offices from 1926 through 1973.

\section{REGULATORY FRAMEWORK OF THE CHILEAN PARLIAMENTARY PRESIDENCY}

The regulatory framework of the Chilean parliamentary Presidency consisted mainly of the Constitution of 1925 and the standing orders of the respective house, regardless of certain legal rules regulating participation of office holders in some institutions.

The Constitution of 1925 established a presidential government to end the executive-legislative stalemate that precipitated the crisis of parliamentary government in 1924, which featured a strengthened presidency and a streamlined legislature (Layseca, 1924). This constitution insisted upon the political irresponsibility of the President of the Republic and the Secretaries, who became 
officials of the exclusive confidence of the Chief Executive, established the incompatibility between parliamentary and executive positions, and substituted permanent tax laws and an annual budget law -that Congress had to pass within four months, for the so-called "periodical laws" (Tapia, 1960). The latter persuaded Kelsen to maintain that this constitution, on the one hand, expressed the antiparliamentary movement that existed at the time and, on the other hand, adopted a moderate solution to the "contemporary problem of restricting the power of Parliament in favor of presidential power. [...] [i]t has been avoided [...] to leave the parliamentary regime to fall at the opposite end of a dictatorship deprived of Parliament" (Kelsen, 2002: 647 s).

Nevertheless, divided government became a feature of the political regime developed under this constitution because of intense partisan competition, a proportional electoral system, and a system of staggered elections that prevented a coincidence between executive and congressional elections (Valenzuela and Wilde, 1979). These circumstances limited presidential authority, even after the constitutional reforms passed in 1970, to the extent that it pointed out that "the critical shift in the balance of governmental power should take place in the parliamentary arena" (Tapia-Videla, 1977: 459). The latter determined that Congress retained a veto by keeping "sufficient powers to make effective government almost impossible for any president who tried to ignore its will" (Tapia-Videla, 1977: 467).

However, the Constitution of 1925 suggested that the Presidencies and Vice-Presidencies of both houses constituted constitutional offices as their holders came to perform specific functions related to the functioning of the new political regime. These functions consisted of taking part in the constitutional subrogation order of the Chief Executive and eventually being a member of the newly created constitutional organ that looked after the legality of presidential and congressional elections, besides the traditional administration and representation of the respective house.

In effect, articles 66 and 69 of the Constitution of 1925 included both the President of the Senate and the President of House of Deputies in the constitutional subrogation order of the President of the Republic, in case of impossibility to exert its constitutional duties by the Chief Executive. Likewise, article 79 of the Constitution of 1925 included the Presidents and Vice-Presidents of both houses into the membership of the Electoral Tribunal. After all, one of its judges should have held the Presidency or Vice Presidency of the House of Deputies for more than a year, and another the Presidency or Vice Presidency of the Senate for the same time.

Instead, there was continuity with the previous period regarding in regulatory matters. The Senate Standing Orders provided for a President and a 
Vice President since 1831, and later versions of these orders passed in 1840, 1917, and even after 1925, did likewise. In turn, the House Standing Orders provided for a President and a First Vice-President since 1831, and later versions of these orders passed in 1846, 1904 and 1924 did likewise, although they created a Second Vice Presidency in 1874.

In the same way, both houses' standing orders regulated the organization and powers of these offices, conferring thus upon each President the representation and administration of each house, who was subrogated by the respective Vice President only in case of absence, illness or resignation. As a result, the President of each house exclusively had the legal capacity to carry out these designated parliamentary functions, according to the aforementioned standing orders ${ }^{2}$.

The President, thus, could represent the house in official ceremonies, subscribe official documentation, direct legislative debates, keep the order inside congressional premises, look after the observance of the standing orders, declare the floor in secret session, declare inadmissible some bill projects, sort and rearrange the order of voting of legislative proposals, grant the use of the word in floor proceedings, solve questions of interpretation or enforcement of the standing orders, if they were clear enough, impose regulatory sanctions on fellow members, and propose the integration of the parliamentary committees, among others.

Finally, some legal and regulatory provisions provided for the membership

of the Presidents of both houses in several special committees, such as, the committee of administration and supervision of the National Congress building, the committee on the Library of the National Congress, and the committee for the appointment and removal of the congressional staff.

\section{INSTITUTIONAL ASPECTS OF THE CHILEAN PARLIAMENTARY PRESIDENCY}

Each house had a President and one or two Vice-Presidents -depending on the house, during the period analyzed herein, so there was a structural continuity with respect to the previous period. The latter is suggests that the Chilean parliamentary Presidency resembled a plural, bureau-like office -called as "the Table" ("la Mesa"), instead of a sole, one-person office, coming thus closer to the French model of plural Presidency, rather than the British or American model of one-person Presidency (Laundy, 1989).

Although standing orders conferred the administration and representation of each house to the President, there was not an obstacle for sharing some limited

\footnotetext{
${ }^{2}$ Interview with the author, Talca, October $24^{\text {th }}, 2014$.
} 
parliamentary work among members of the Table, which made plenty of sense in case of prior electoral agreements ${ }^{3}$. Moreover, the President and Vice-Presidents looked after internal administrative matters through their membership in the Senate Committee of Interior Police and the House Committee of Interior Regime, Administration, and Standing Orders, as the case may be, which dealt with such matters. Likewise, they were members of the Committee on Order of Legislative Businesses of each house, which dealt with setting the agenda of ordinary sessions thereof, along with the Chairs of the Senate standing committees and the House parliamentary caucuses. In any case, any deputy could ask for the observance of the standing orders and any parliamentary caucus could file a complaint about the conduct of the Table or the rulings made by the President of the Senate, which limited the extent of presidential authority.

Regarding the length of their office terms, the President and the Vice Presidents of the House of Deputies were elected at the beginning of each ordinary session from 1926 to 1935, whereas the same rule applied to the President and the Vice President of the Senate from 1926 to 1954; therefore, they all could spend a year in office. Regulatory reforms passed in 1935 in the House and in 1954 in the Senate provided for their election at the beginning of each legislative period, precisely to strengthen their authority in the legislative process. Even though these reforms made possible their permanence in office for a quadrennium, they did not mean to ignore that their holders rested on the support of a parliamentary majority.

Ultimately, these reforms sought to combine an impartial exercise of the duties and authority vested in these offices with the partisan origins of Presidents and Vice Presidents. In functional terms, these reforms approached the Chilean parliamentary Presidency to the model of parliamentary Presidency called "Speaker of the House", which is similar to a partisan Presidency in formal terms of power, but exercises the authority of the office in a non-partisan way (Jenny and Müller, 1995). Former President of the Senate, Mr. Pablo, illustrated the latter, as follows: "when one looks at the Senate members from the front of the Corporation in function of the office of the Presidency, it is perceived a different vision of them than the one usually held from a parliamentary bench. / [...] The Table has to impose order, suppress words that are deemed anti-parliamentary, etc." (Pablo, 1971: 41-43).

However, the latter did not ignore that the Presidents and Vice Presidents of both houses responded to a particular political persuasion that made possible their election to the office and justified their vote and use of the word on the floor. Precisely, these circumstances made possible for them to join forces with the

\footnotetext{
${ }^{3}$ Interview with the author, Talca, October 24 $4^{\text {th }}, 2014$; Talca, November 10 2014.
} 
parliamentary majority and to become relevant negotiators in the legislative process sometimes ${ }^{4}$. Consequently, it is hardly surprising that Engber maintained that the Chilean Presidents -and Vice-Presidents, were halfway between a partisan and a non-partisan model of parliamentary Presidency by the late 1960s, identified with the American and the British Speakership, respectively, after taking into account their exercise of office powers and the circumstances surrounding their election to office (Engber, 1967).

\section{INSTITUTIONAL DYNAMICS ON THE CHILEAN PARLIAMENTARY PRESIDENCY}

For purposes of studying the institutional dynamics generated around these offices, this research considered only the proprietary Presidents and Vice Presidents of both houses elected from 1926 to 1973 . As such, it did not consider the provisional or provisory Presidents and Vice Presidents elected in the same period because these were interim officials elected before the inauguration of a new legislative period, after which they resigned to their offices. Furthermore, they may determine an artificially high rotation on the designated offices, distorting thus the analysis carried out herein.

Accordingly, it is apparent that very few Presidents and Vice-Presidents completed a quadrennium after 1949 in the House and almost none after 1954 in the Senate, with nearly thirty elections to these offices, as shown in Tables $\mathrm{N}^{\circ} 1$ to 5 (see Tables $\mathrm{N}^{\circ} 1$ to 5 ). Therefore, very few Congress members rose to these offices more than once, being the access to these positions more competitive in the House than in the Senate. For example, only a single deputy served as House President more than once, while six senators did likewise in the Senate, which does not differ much from the remaining positions of both houses' Tables.

The high number of elections reported above suggests that access to the Presidencies -and Vice Presidencies as well, constituted a political resource appreciated by Congress members. After all, the office gave their holders a national projection, as they became the face of the house before the public, endowed as well with some institutional perquisites. Sometimes the President could become the key player to unlock the legislative process, revealing thus his or her leadership skills. Eventually, a satisfactory performance was likely to lead to a cabinet position a party leadership positions, a Senate seat or even a nomination for the Presidency of the Republic 5 . Yet, only two Presidents or Vice Presidents rose to the Chief Executive office, i. e.

\footnotetext{
${ }^{4}$ Interview with the author, Santiago, October $16^{\text {th }}, 2014$.

${ }^{5}$ Interview with the author, Santiago, October $7^{\text {th }}$, 2014; Talca, October 24 ${ }^{\text {th }}$, 2014; Talca, November $10^{\text {th }}, 2014$.
} 
González Videla and Allende Gossens. Consequently, the authority vested in these offices played an instrumental role regarding the aforementioned parliamentary duties and the satisfaction of self-interest of Congress members, e. g. projection or maintenance of a political career. The latter may explain that two Presidents of the Republic subsequently occupied the Senate Presidency, i. e. Alessandri Palma and Frei Montalva.

However, both Presidents and Vice Presidents did not usually last a quadrennium in office, which seems strange because of the importance of the parliamentary Presidency. Notwithstanding the low probability of constitutionally subrogating the Chief Executive, the partisan origins of those who rose to these offices limited the influence of their self-interest and, therefore, the length of their stay in office. Indeed, political parties with parliamentary representation favored the election of someone from their ranks to these offices, because it swelled the roster of potential party candidates to the Electoral Tribunal, for which purpose party discipline and honoring partisan agreements played a key role.

Nevertheless, these circumstances do not imply that both houses elected chose members lacking parliamentary experience to these offices. In fact, according to Tables $\mathrm{N}^{\circ} 1$ to 5, no House President served less than 1.6 years in this house, except Quiroga Arenas (1931), no First House Vice President served less than 2.2 years therein, except Bernales Navarro (1941) and Señoret Lapsley (1969), and finally, only two Second House Vice-Presidents lacked parliamentary experience, i. e. Ernst Martínez (1941) and the De la Presa Casanueva (1953).

In this sense, almost all of those who rose to these offices previously served in either house of the Chilean legislature and had a parliamentary experience that stretched on average from 5.24 to 15.18 years, according to Figure No. 1, computed from the aforementioned tables (see Figure $\mathrm{N}^{\circ} 1$ ):

\begin{tabular}{|c|c|c|c|}
\hline Office & Same House & Both Houses & Total Elections \\
\hline House President & 7,58 & $\ldots$ & 33 \\
\hline First House Vice President & 8,51 & $\ldots$ & 31 \\
\hline $\begin{array}{c}\text { Second House Vice } \\
\text { President }\end{array}$ & 5,24 & $\ldots$ & 34 \\
\hline Senate President & 8,72 & 15,18 & 29 \\
\hline Senate Vice President & 7,9 & 12,84 & 38 \\
\hline
\end{tabular}

Figure No 1: Average previous parliamentary experience of Presidents and Vice Presidents of both houses. Elaboration by the author. 
In addition, very few Congress members rose to all positions of both houses' Tables. Therefore, being elected to a Vice Presidency did not guarantee a future Presidency for Congress members; in fact, only four First House Vice-Presidents were elected House Presidents later, as shown in Figure $\mathrm{N}^{\circ} 2$, drawn up from Tables $\mathrm{N}^{\circ} 1$ and 2 (see Figure $\mathrm{N}^{\circ} 2$ ):

\begin{tabular}{|c|c|c|}
\hline Deputy & First Vice Presidency & Presidency \\
\hline Guzmán García & 1929 & 1935 \\
\hline Tapia Moore & 1949 & 1950 \\
\hline Correa Letelier & 1953 & 1957 \\
\hline Pareto González & 1967 & 1973 \\
\hline
\end{tabular}

Figure $\mathbf{N}^{\circ}$ 2. First House Vice Presidents elected House Presidents. Elaboration by the author.

Also, only four Second House Vice-Presidents became First House VicePresidents, whereas two Second House Vice-Presidents became House Presidents, without always matching their identities according to Figure $\mathrm{N}^{\circ} 3$, drawn up from Tables $\mathrm{N}^{\circ}$ 1, 2 and 3 (see Figure $\mathrm{N}^{\circ} 3$ ):

\begin{tabular}{|c|c|c|c|}
\hline Deputy & $\begin{array}{c}\text { Second Vice } \\
\text { Presidency }\end{array}$ & First Vice Presidency & Presidency \\
\hline Letelier Elgart & 1926 & 1928 & $\ldots$ \\
\hline De la Jara Z. & 1928 & 1933 & $\ldots$ \\
\hline Rivera Baeza & 1930 & $\ldots$ & 1933 \\
\hline Santandreu Herrera & 1941 & $\ldots$ & 1944 \\
\hline De la Presa Casanueva & 1953,1957 & 1958 & $\ldots$ \\
\hline Acevedo Pavez & 1969 & 1970 & $\ldots$ \\
\hline
\end{tabular}

Figure $\mathbf{N}^{\circ}$ 3. Second House Vice Presidents elected First House Vice Presidents and House Presidents. Elaboration by the author.

Neither the election to any of these House offices determined a subsequent election to the Senate Presidency or Vice Presidency, as only made it to these Senate offices two House Presidents (i. .e. Urrejola Menchaca, 1926, and Maurás Novella, 1958, were elected Senate President in 1944 and 1966, respectively), one First House Vice President (i. e. Sepulveda Garcés, 1957 and 1960, was elected Senate Vice President in 1966), and two Second House Vice Presidents (Palma Vicuña, 1958, and Papic Ramos, 1965, were elected Senate President and Vice-President in 1972, respectively). 
Regarding the Senate, it is apparent that only six senators occupied both offices of the Senate Table, as shown in Figure 4 below, drawn up from Tables $N^{\circ} 4$ and 5:

\begin{tabular}{|c|c|c|}
\hline Senator & Vice Presidency & Presidency \\
\hline Cabero & 1930 & 1933 \\
\hline Videla Lira & 1944 & 1958,1961 \\
\hline Allende Gossens & 1951,1953 & 1966 \\
\hline Pérez de Arce Plumer & 1957 & 1958 \\
\hline Alvarez Suárez & 1962 & 1949 \\
\hline
\end{tabular}

Figure $N^{\circ}$ 4. Senate Vice Presidents elected Senate Presidents. Elaboration by the author.

Although the rigors of electoral competition and the length of congressional terms constituted obstacles for an extended congressional career, the data offered hereabove strongly suggests the existence of a profile requirement to rise to the offices of both houses' Tables, which related to the previous parliamentary experience and role in the legislative process, e. g. Presidencies of both houses. In other words, some offices were not available for certain Congress members according to the political appreciation of their peers. The data also suggests that the real political projection of such offices was quite uncertain for the vast majority of their holders, given the intraelite competition that presided over their access and the self-contained nature of the internal processes of the Chilean legislature. In this regard, the Chilean legislature ended up building an effective barrier to access to the parliamentary Presidency, which prevented the external environment from intruding into such process through the election of newly elected Congress members, in contrast to the previous period. 


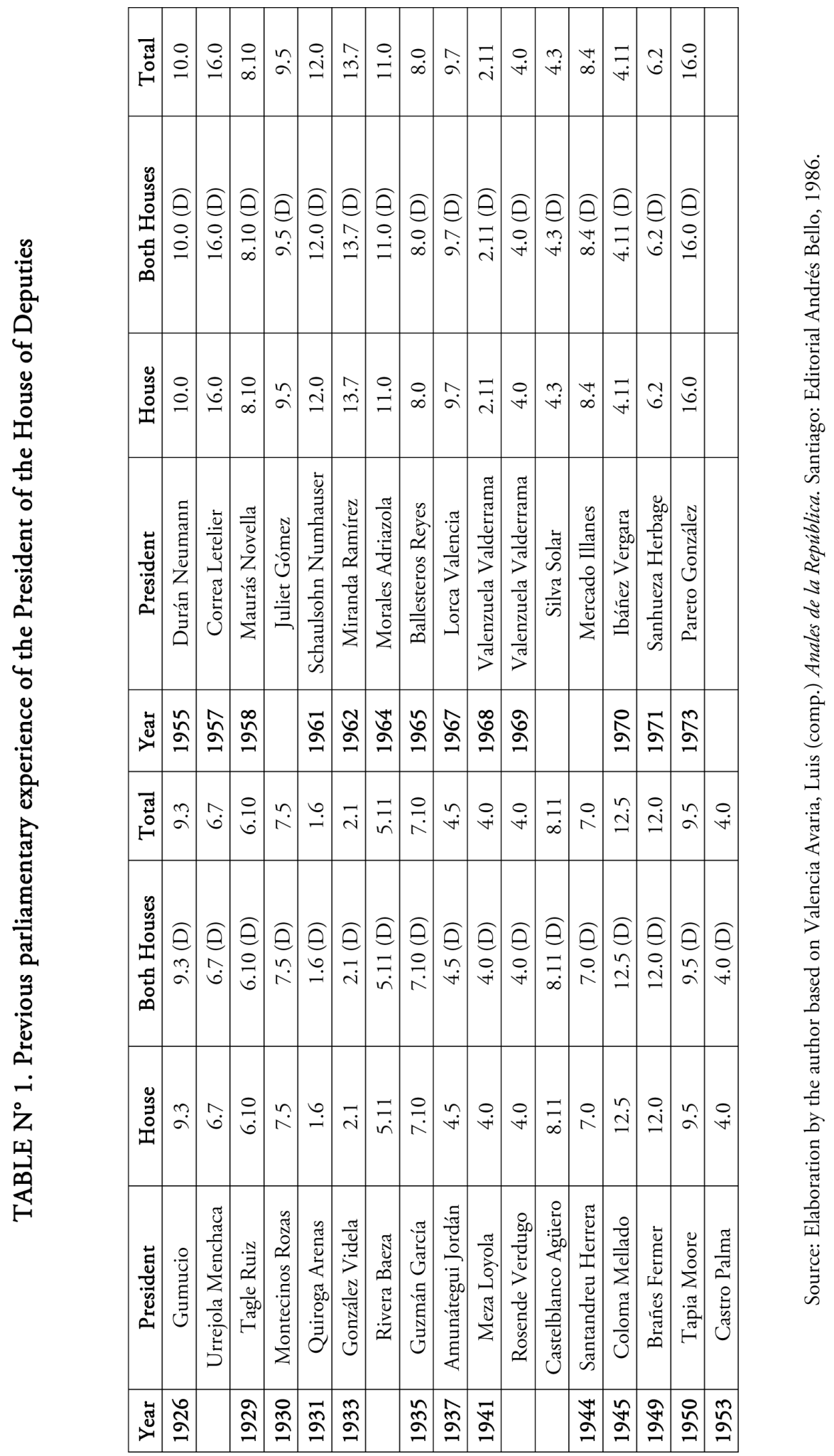




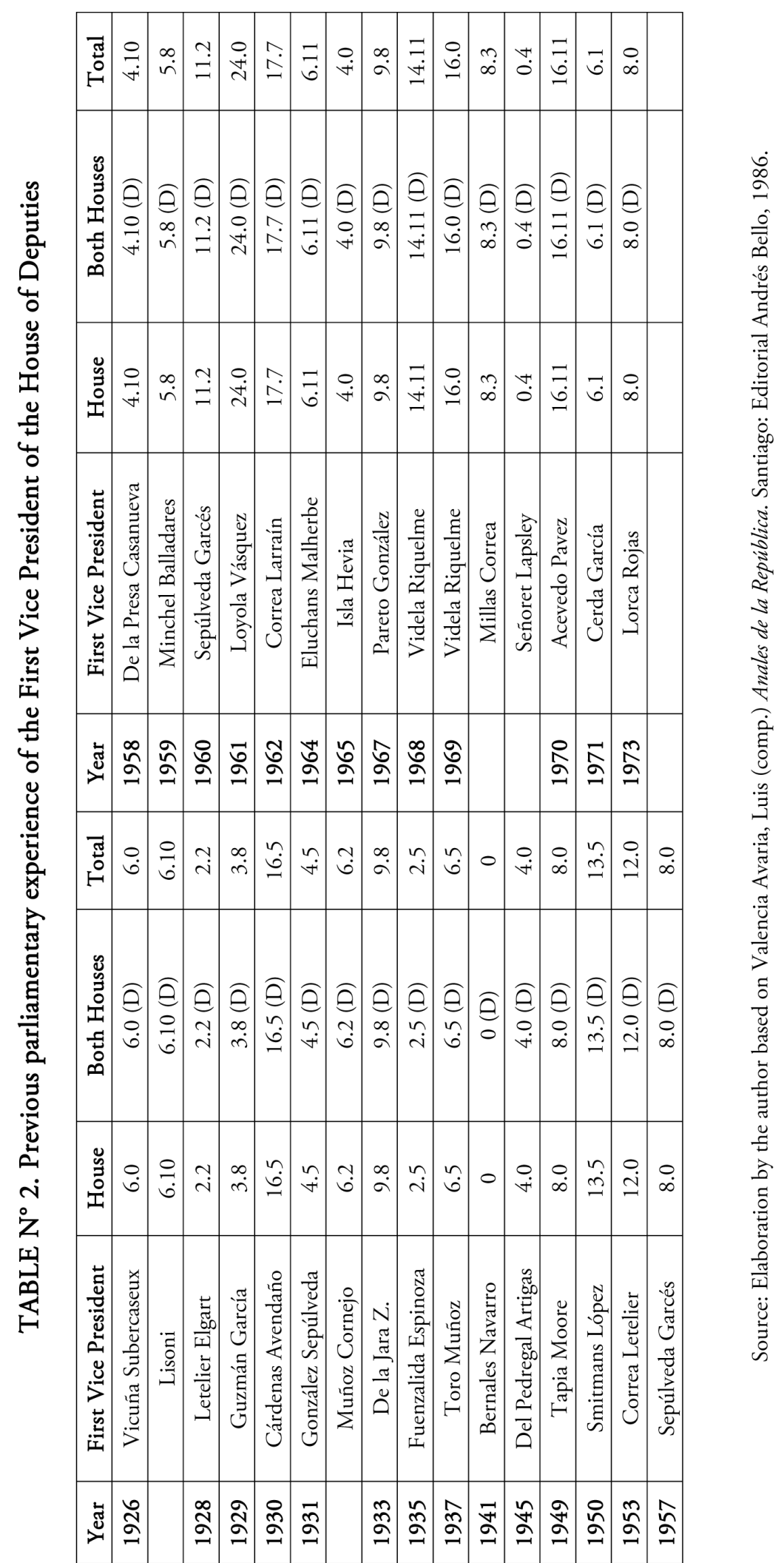




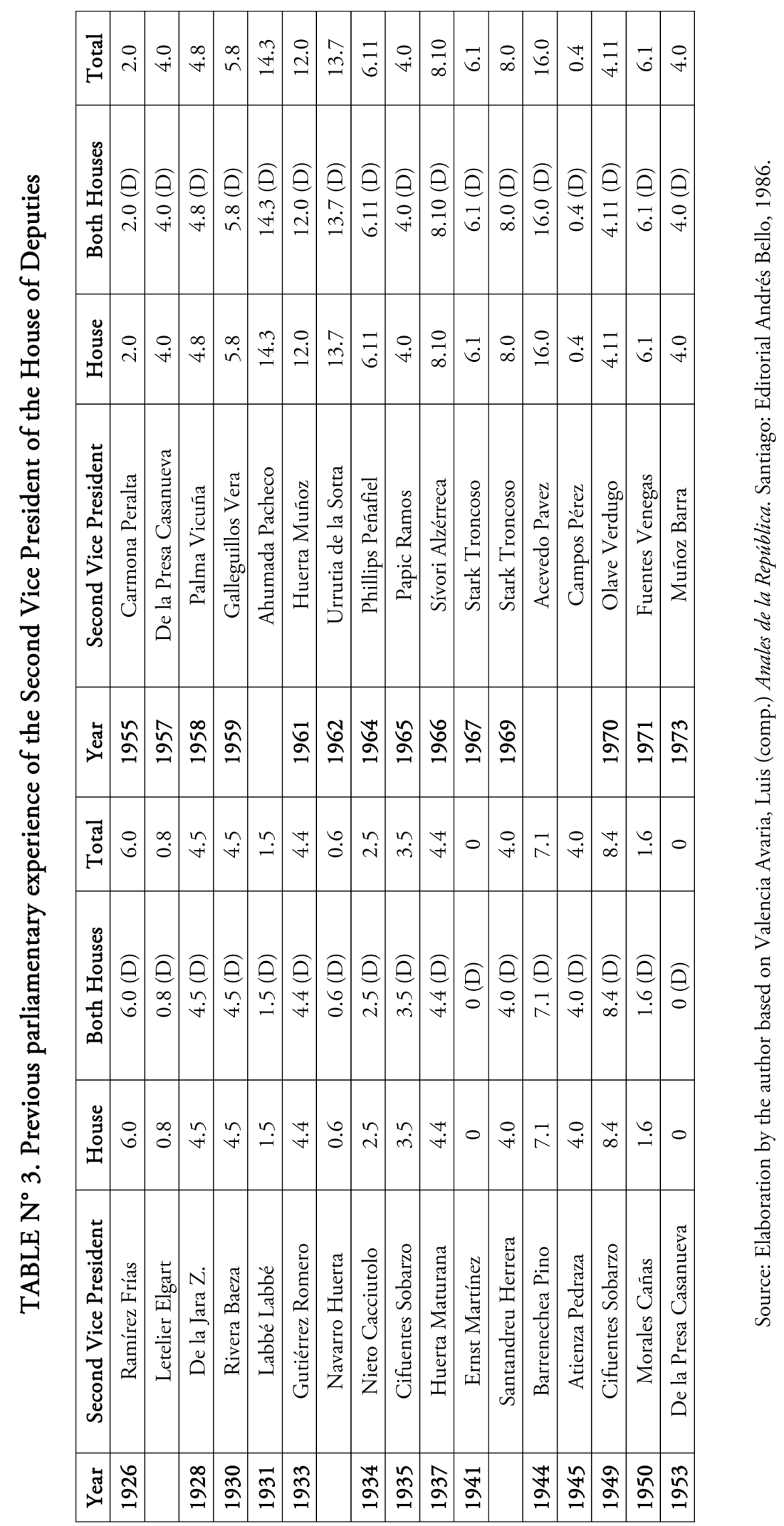




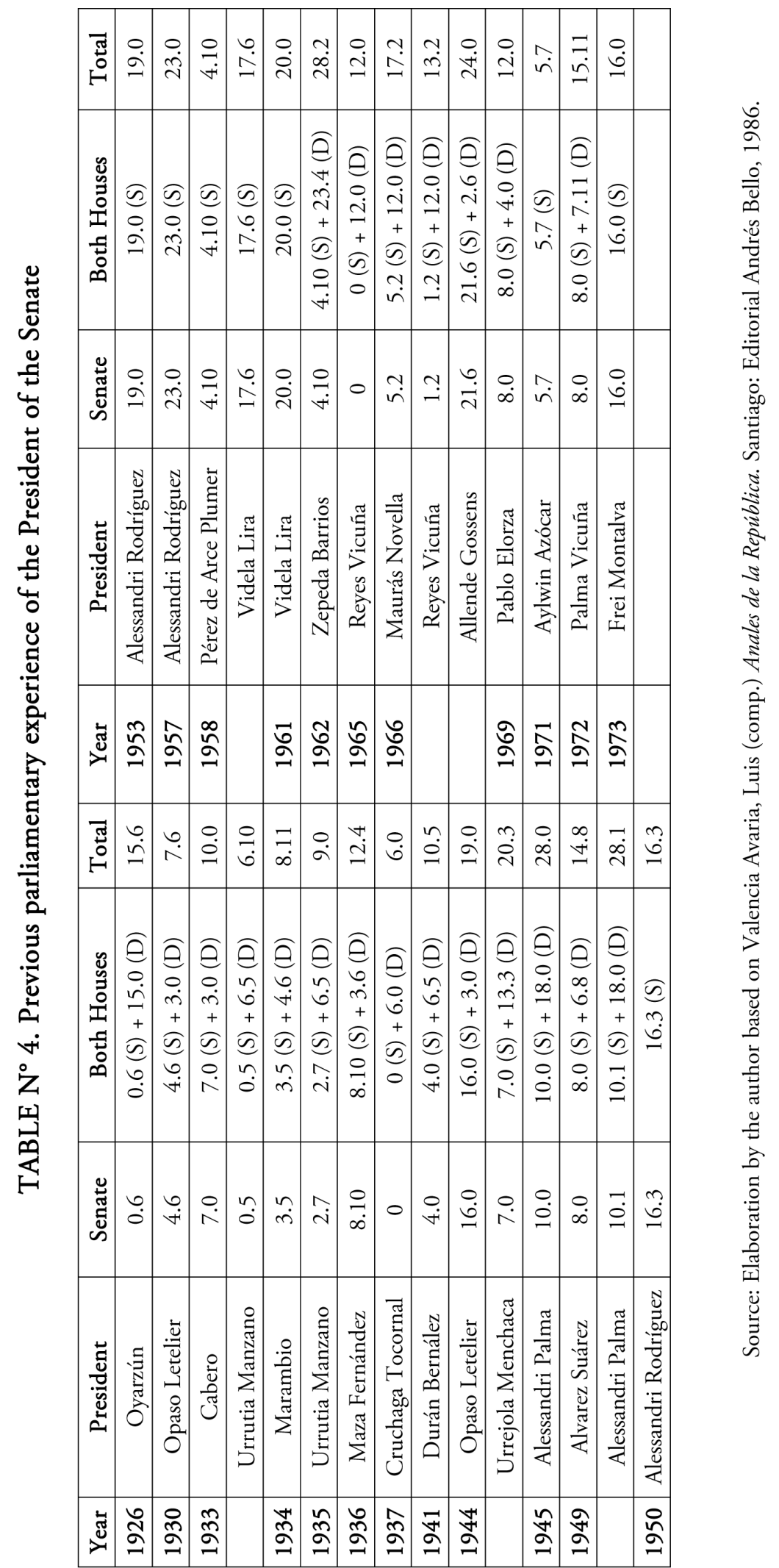




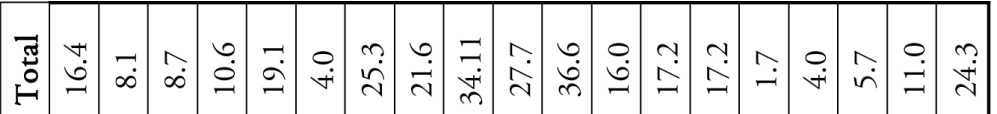

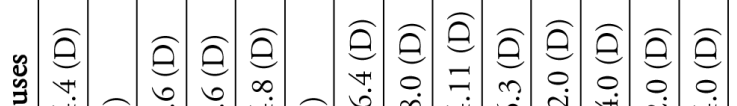

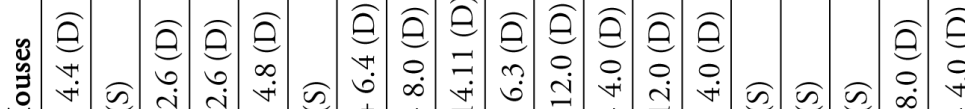

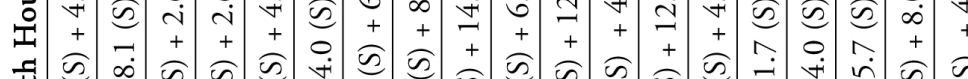

苛

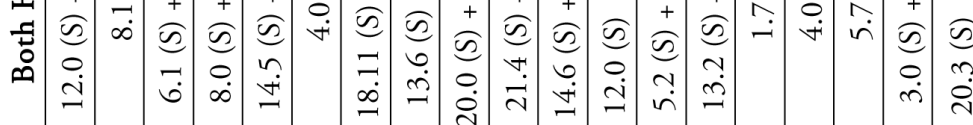

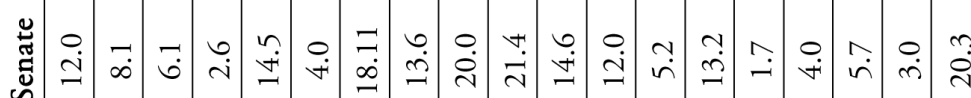

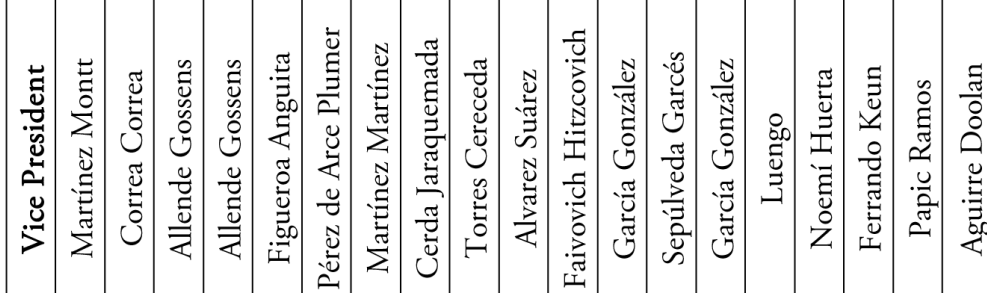

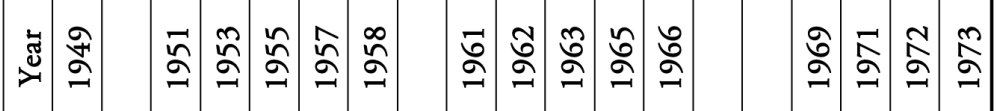

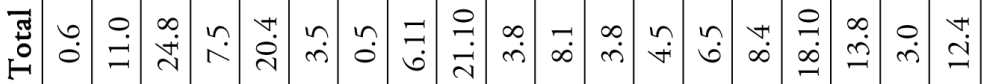

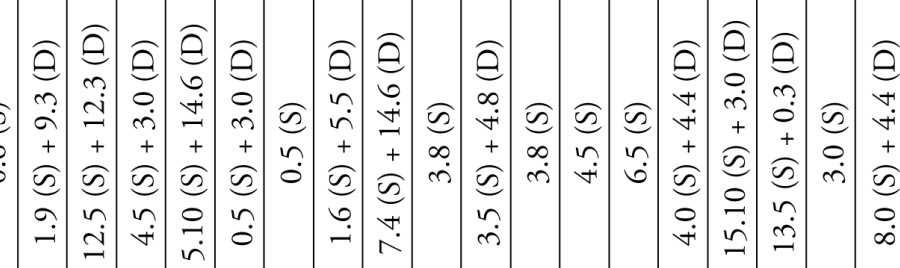

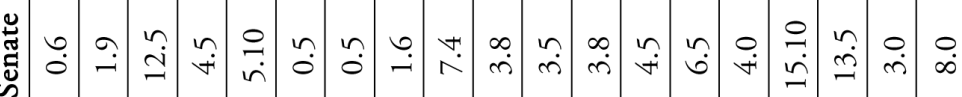

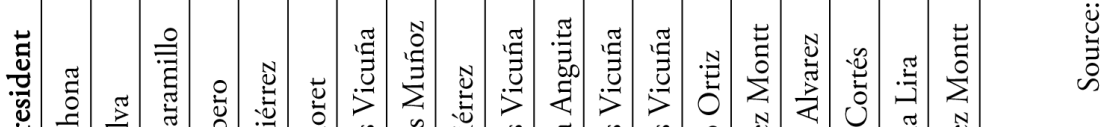




\section{CONCLUSION}

The Presidencies and Vice-Presidencies, of both houses constituted constitutional offices in the period analyzed herein, returning thus to a tradition interrupted in 1833. Nevertheless, there was some continuity with the previous period regarding their powers and structure. In fact, the mere presence of a President and one or two Vice-Presidents at both houses' Tables suggests that the Chilean parliamentary Presidency resembled a plural, bureau-like office from a structural point of view, regardless of the degree of effective intervention of Vice Presidents in the administration and representation of each house.

Despite the partisan origins of those elected to these offices and the fact that they voted and made use of the word on the floor, there was a peers expectation that office holders performed impartially the duties and authority vested in their offices, which explains the passage of regulatory reforms that took aim at strengthening these offices. These circumstances ended up placing the Chilean parliamentary Presidency halfway between a partisan and a non-partisan model of parliamentary Presidency, identified with the American and the British Speakership, respectively.

In contrast to the previous period, both houses' offices interested Congress members for reasons related to the projection of their political careers, for which purpose it became useful the exercise of office powers and the public exposure afforded by the respective office, although within a power structure that relied on the political parties with parliamentary majority.

In the same way, the access to such offices required prior parliamentary experience, excluding thus by general rule, newly elected Congress members, conversely to the previous period. The latter implied building a barrier with regard to the external environment of the Chilean legislature, precisely at a time in which the country underwent deep social and political changes.

\section{REFERENCIAS}

Cámara de Diputados. "Reglamento de la Cámara de Diputados de $1^{\circ}$ de marzo de 1926". Reglamento de la Cámara de Diputados. En Cámara de Diputados. Santiago, Chile: Imprenta Rapid, (1930): 7-59.

Cámara de Diputados. "Reglamento de la Cámara de Diputados de 21 de mayo de 1941". Reglamento de la Cámara de Diputados y Constitución Política de la República de Chile. En Cámara de Diputados. Santiago, Chile: s.e., (1945): 33-87. 
Cámara de Diputados. "Reglamento de la Cámara de Diputados de 16 de septiembre de 1971". Reglamento de la Cámara de Diputados y Constitución Política de la República de Chile. En Cámara de Diputados. Santiago de Chile: s.e., (1971): 5-122.

Engber Alvarez, Víctor. "Los Presidentes de las Cámaras”. Memoria de Prueba. Chile: Universidad de Chile, 1967.

Jenny, Marcelo \& Müller, Wolfgang C. "Presidents of Parliament: Neutral Chairmen or Assets of the Majority?" Parliaments and Majority Rule in Western Europe. En Döring, Herbert (Ed.), New York: St. Martin's Press, (1995): 326-364.

Kelsen, Hans: "Observaciones sobre la Constitución chilena". Traducción de Joaquín García Huidobro, Anuario de Filosofia Jurídica y Social 20 (2002): 643-647.

Layseca A., Rubén. Un Momento Histórico Político de la Vida Nacional. El conflicto del ejecutivo y la mayoría del Senado. Santiago, Chile: Imprenta Soc. Boletín Comercial, 1924.

Laundy, Philip. Parliaments in the Modern World. Aldershot, Darmouth Publishing Company Ltd., 1989.

Ministerio del Interior. Actas Oficiales de las Sesiones celebradas por la Comisión y subcomisiones encargadas del estudio del Proyecto de Nueva Constitución Politica de la República. Santiago, Chile: Imprenta Universitaria, 1925.

Pablo Elorza, Tomás. El Congreso Nacional visto desde su Presidencia. Santiago, Chile: Editorial Andrés Bello, 1971.

Senado. "Reglamento del Senado de 30 de marzo de 1926". Constitución Política y Reglamento del Senado de la República de Chile. En Senado. Santiago, Chile: Soc. Imp. y Lit. Universo, (1926): 72-138.

Senado. "Reglamento del Senado de 21 de mayo de 1936". Manual del Senado 1810-1942. En Senado. Santiago, Chile: Imprenta Universitaria, (1942): $107-172$. 
Senado. "Reglamento del Senado de $1^{\circ}$ de agosto de 1954". Manual del Senado. En Senado. Santiago, Chile: Editorial Universitaria, (1966): 109-235.

Tapia Valdés, Jorge A. La Técnica Legislativa. Santiago, Chile: Editorial Jurídica de Chile, 1960.

Tapia-Videla, Jorge. "The Chilean presidency in developmental perspective", The Journal of Interamerican Studies and World Affairs 19 (1977): 451-481.

Valenzuela, Arturo y Wilde, Alexander. "Presidential Politics and the Decline of the Chilean Congress". Legislatures and Political Development. En Smith, Joel y Musolf, Lloyd S. (Eds.), Durham: Duke University Press, (1979): 189-215.

Valencia Avaria, Luis (comp.) Anales de la República. Santiago, Chile: Editorial Andrés Bello, 1986. 